\title{
The garnet of diamond association in lamprophires from the Anabar massif.
}

\author{
V. P. Kornilova, A. F. Safronov, N. D. Philipov, A. I. Zayzev
}

Yakutian Institute of Geological Sciences, Sibirian Branch, Russian Academy of Sciences.

Prospecting works carried out in Proterozoik limestones in the southeastern part of the Anabar massif reveal pipes and dykes of alkali-ultrabasic rocks with high- $\mathrm{Cr}$, low-Ca garnets in one of them (the Olobw-6 pipe). The rocks from this pipe differ in features from kimberlites and are compatible with mica-pyroxene picrites.

The rock texture is fine- and mediumporphyritic with individual large (up to 10-20 $\mathrm{mm}$ ) segregations of olivine grains, frequently serpentinized. Xenogenic material is absent. Insets account for about $50 \%$ of the rock volume. These are olivine and rare phlogopite and ilmenite. The groundmass is composed of phlogopite $(20-30 \%)$, ore minerals $(10 \%)$, apatite $(1 \%)$, varying amounts of clinopyroxene $(1-10 \%)$, as well as serpentine and carbonate (no more than $10-15 \%$ in total). Clinopyroxene is frequently carbonatized. Ore minerals include are titanium-bearing ferrispinel, perovskite, ilmenite, and small amounts of sulfides. Perovskite is the most abundant mineral. Ferrispinel and perovskite occurs both as unaltered and completely decayed grains. Decomposition products of perovskite are irregular small carbonate crystals intermixed with equidimensional accumulations of titanium oxides. The latter may include irregular grains of ilmenite. Sulfide minerals are reprezented by pyrite and chalcopyrite.

Olivine contains 9.5 - $16.6 \mathrm{~mol} \% \mathrm{Fa}$ and up to $0.15 \mathrm{wt} \% \mathrm{CaO}$. Phlogopite insets are chloritized, so we failed to make reprezentative analyses. Phlogopite of the groundmass is rich in $\mathrm{Ti}(3.3-3.5 \mathrm{wt} \% \mathrm{TiO})$. The $\mathrm{Fe} /(\mathrm{Mg}+\mathrm{Fe})$ is no more than 0.176 . Clinopyroxene occurs as diopside. A charucteristic feature of diopside is a high content of sodium oxide (up to 1.3-1.4 wt.\%) in individual grains. Ferrispinel of the diopside is a groundmass is represented by titanomagnetite, sometimes high- $\mathrm{Cr}\left(13.2 \mathrm{wt}^{\mathrm{o}} \% \mathrm{Cr}_{2} \mathrm{O}_{3}\right)$ and low-Al (no more than $0.9 \mathrm{wt} \%$ $\mathrm{Al}_{2} \mathrm{O}_{3}$ ) in content. Ilmenite is compatible in composition with $\mathrm{Mn}$-bearing crichtonite. Concentrations of $\mathrm{MgO}$ do not exceed $1.5 \mathrm{wt} . \%$ and that of $\mathrm{MnO}$ vary in the range of 0.4 to 1.5 wt. \%. Perovskites are poor in REE. Carbonate occurs as ankerite containing up to 6.4 wt. $\% \mathrm{FeO}, 14.7 \mathrm{wt} . \% \mathrm{MgO}$, and $28.8 \mathrm{wt} . \% \mathrm{CaO}$.

Heavy fractions of samples contain chromous pyrope ,almandine, picroilmenite, and ilmenite. Chromite is absent. $\mathrm{FeO}, \mathrm{Cr}_{2} \mathrm{O}_{3}$ and $\mathrm{CaO}$ contents of $\mathrm{Cr}$-pyropes are 5.9 to 12.9 wt. $\%, 0.2$ to $11.4 \mathrm{wt} \%$ and 4.2 to $7.0 \mathrm{wt} . \%$, resprectively. Five of 106 garnet grains analyzed represent the diamond-association garnets.

Picroilmenite has a composition typical of kimberlite rocks. A distinctive feature is a low concentration of $\mathrm{Cr}_{2} \mathrm{O}_{3}$ (no more than $0.5 \mathrm{wt} . \%$ for most grains). Ilmenite is compositionally similar to ilmenites of groundmass.

Concentrations of $\mathrm{TiO}_{2}, \mathrm{Al}_{2} \mathrm{O}_{3}$, and alkalies are high in the rocks.

The age of three rock spesiments is estimated at 206 to $228 \mathrm{~m}$.y. by the Rb-Sr method. Values of the $\mathrm{Sr}$ isotope ratio vary from 0.7034 to 0.7048 which is probobly due to secondary alteration of rocks.

The above rocks differ from kimberlite by a number of features. These are crichtonitic composition of ilmenite and ankeritic composition of carbonate of the groundmass. The studied rocks also contain diamond-association garnets of, which makes them different from the rocks of the adjacent kimberlite fields (Kuranakh, Luchakan and Dyuken fields). We have previously studied compositions of garnets from 20 kimberlite bodies of these fields. Only some of the bodies( Pozdnyaya-2 kimberlite pipe, Luchakan field) and alnoite-like rock from one of the dykes within the Anabar massif contain comparable amounts of garnets of this paragenesis. 
Thus, the presence of diamond-association garnets in the lamprophyres of the Anabar massif suggest they contain diamonds. It is quite possible that such rocks are sources of diamond placers in the north of the Yakutian province. 